\title{
BIO-ORIENTED AGRARIAN ECONOMY INVESTMENT PROGNOSIS IN THE EU COUNTRIES
}

\author{
Valeriia Lymar ${ }^{1}$
}

\begin{abstract}
The purpose of the investigation is making a prognosis of bio-oriented agrarian economy investment in the EU countries and preparing a set of steps how to attract investment in the bio-oriented agrarian economy sectors. Nowadays investment is one of the critical factors of bio-oriented agrarian economy development. It was set as one of the priories in the European Strategy 2020, where they defined the bio-oriented economy as the main engine for smart and innovation growth in Europe. Methodology. To make a prognosis, it was used BP Stat program, namely Brown's, Holt's, Box-Jenkins, and Olympus' methods. Results. In the third millennium, the global community faced many objective problems, which need cooperation and relations between nations to solve them. There were defined such challenges: climate changes, the growth of the global population, exhaustion of limited resources and others. To meet these challenges, the European Commission proposed the bio-oriented agrarian economy concept, which is an interdisciplinary phenomenon and combines elements of several fields of science: economy, management, chemistry, biology, pharmacy, physics, and mathematics. In accordance with the EC classification, there are such bio-oriented economy sectors: food, agriculture, paper/pulp, forestry/wood industry, fisheries and aquaculture, bio-chemicals. The main aim of the bio-oriented agrarian economy is a smart use of biological resources to produce healthy food and feed and minimizing the use of limited resources. During the investigation, there were given arguments and explained the necessity of bio-oriented agrarian economy development both on the EU and national levels. It was proved that without investment, it is impossible to develop such a concept. Practical implementations. Obtained prognosis allows to predict the dynamic of bio-oriented agrarian economy investment in Europe and develop a set of steps how to attract investment in this sphere, namely to invest in research and innovation sectors; support commercialization of knowledge and innovation; promote entrepreneurship in the sectors of bio-oriented agrarian economy; develop an innovation-friendly regulatory framework and support creating new jobs in the bio-oriented agrarian economy sectors. Value/originality. Results of the investigation help to improve the theoretical base of bio-oriented agrarian economy concept development and show the importance of investment of bio-economy sectors as on the national levels and on the European one.
\end{abstract}

Key words: investment policy, investment in agriculture, bio-oriented agrarian economy, biotechnologies, food and feed, bio-based products, green growth.

JEL Classification: O13, Q14, Q16

\section{Introduction}

The third-millennium economy is characterized by innovation and use of $R \& D$ in all spheres: from production to prediction of customers' needs and wishes and providing services. In addition, it is necessary to pay attention to the interdisciplinary phenomenon, biooriented agrarian economy, which integrates results of different fields of science, production, agriculture, and management.

The bio-oriented agrarian economy is the innovative challenge today. It has supporters and opponents. Such interdisciplinary phenomenon causes many questions and cannot exist without interest of those, who are interested in modern scientific tides and understand the

Corresponding author:

${ }^{1}$ Vasyl Stus Donetsk National University, Ukraine.

E-mail: limval555555@gmail.com necessity of finding answers on global challenges, which society face with nowadays.

Modern marketing economy is the complex organizational mechanism with a big number of horizontal and vertical relations, which uses different resources and depends on the complex of selfgovernance instruments and methods of influence. The result of the activity of such a mechanism is the profitability and the effectiveness of business agents.

The effectiveness of the bio-oriented agrarian economy in the modern difficult conditions of the market conjunction needs fast decisions and nonstandardized approaches to the production organization, development of relations with business partners, as well 
as the new economic vision of agricultural products producers.

Changes that nowadays take place in the system of economic relations, in particular, in the sphere of government regulation must be based as well as on the general regularities of market mechanisms and on the priorities of national development and functioning features and development of national agrarian economy in the context of its integration into the global economy.

The bio-oriented agrarian economy is aimed at the investigation of methods of optimization of the use of limited resources for production, processing, selling, and consumption of food. It is necessary to note that in agriculture, which is the main sector of the bio-oriented agrarian economy, the main economic laws act.

Last two decades, biotechnology has become an important factor for stable producing and development of neoteric products and services. The economical application of biotechnologies has to cause the bio-oriented agrarian economy growth and development, where a real share of outcomes depends on the application of biological and raw materials. The commercial and environmental advantages of biotechnologies have made an interest in the bio-oriented agrarian economy in many countries. Although, for the bio-oriented agrarian economy to grow, it is necessary to analyse its investment support and offer the plan of actions on how to attract the attention of investors to the bio-oriented economy sectors.

\section{Literature review}

Before analysing and making a prognosis of biooriented agrarian economy investment, we are going to highlight scientific works of some prominent native scholars. For Ukrainian scientists, it is relatively new and we are sure that it has not been studied very deeply yet. Although there are papers of Ukrainian scientists that deserve attention, in particular, we highlight papers of Baidala V. (2016); Volivach V., Kozlovska M., Kravchenko O. (2016), Matyushenko I. (2015), Selinnyi M. (2014), Pogrishchyuk B., Martusenko I. (2016), Butenko V. (2016), Proshchalkina A. (2016) and Gerasimchuk N. (2013), Talavyria M., Lymar V., Baidala V. (2015), Kozlovskyi S., Grynyuk R., Baltremus O., Ivashchenko A. (2017), Kozlovskyi S., Khadzhynov I., Vlasenko I., Marynchak L. (2017).

Above-mentioned investigations are devoted to working out theoretical basis of formation and development of bio-oriented agrarian economy in Ukraine, namely, to the directions of bio-oriented economy's development, investigation of the bio-economic factors of the region's agriculture development, concept of the resource-saving in the bioeconomy system and defining prospects of this concept development in the future.

Investigations of Ukrainian scientists play a significant role in the development of the bio-oriented agrarian concept, but it is necessary to highlight the contribution of European colleagues. The most interesting for our investigation are papers of Maciejczak M. (2015), Carrez D. (2008), Carlson R. (2008), Birch K., Tyfield D. (2012), Goven J., Pavone V. (2014).

Especial interest for the investigation has works of the European Commission experts, in particular, devoted to the knowledge bio-based economy - KBBE (The Knowledge Based Bio-Economy (KBBE) in Europe: Achievements and Challenges, 2010), sustainable growth and global challenges (Delivering Sustainable Growth by addressing the Grand Societal Challenges, 2014), prospects of bio-economy development to 2030 (The Bioeconomy to 2030. Designing a policy agenda. Main Findings and Policy Conclusions, 2009), importance of private and financial investors for the bio-economy (Importance of Private and Financial Investors for the Bioeconomy. Current Situation in Europe and Recommendations, 2014), innovations for sustainable growth (Innovating for Sustainable Growth: A Bioeconomy for Europe, 2012).

\section{Methods}

During the investigation, there were used such scientific methods: analysis (analysing approaches to the bio-oriented agrarian economy definition); synthesis (defining difference between traditional and agrarian economy); comparison (comparing investment of biooriented agrarian economy in the EU countries and Ukraine); abstraction, concretization, summarizing, formalization, induction, deduction, and analogy (defining the specific features of the bio-oriented agrarian economy in Ukraine and its sectors). In addition, we used BP Stat programming for developing a prognosis of the bio-oriented economy investment in the EU counties.

\section{Results}

To manage the global population, increasing environmental population and changes of climate, there is the necessity of changes of approach to the production, consumption, processing, storage, recycling of bioresources. The Europe Strategy 2020 calls for the biooriented agrarian economy as the key element for the smart and green growth in Europe. Achievements in the bio-oriented agrarian economy $R \& D$ uptake will convince Europe to develop the management of its renewable bio-resources and to open new markets of bio-based products. Developing the bio-oriented agrarian economy in Europe has a great potential: it can cause economic growth and jobs in rural territories, reduce fossil fuel dependence and improve the economic sustainability of primary production and processing industries. The biooriented agrarian economy contributes to the purposes of the Europe 2020 flagship initiatives "Innovation Union" and "Resource Efficient Europe". 
The new EU research and innovation program "Horizon 2020" which has a budget of 70 billion euro defines the importance of bio-oriented agrarian economy development for reduction of dependence on non-renewable and limited resources, adaptation to changes of climate, smart use of natural resources, food security, economic growth, creating new jobs and nations competitiveness in general.

Thus, according to the "Horizon 2020" "Knowledgebased Bioeconomy" - KBBE program was established. Today it is the part of the EC Strategy "Innovating for Sustainable Growth: a Bioeconomy for Europe".

It is necessary to highlight programs "Sustainable Food Security" with the budget of 138 million euro and "Blue Growth" with the budget of 100 million euro. Budgets of these programs are directed to the bio-oriented agrarian economy in Europe, where Finland, Ireland, Swiss, and Norway have already affirmed strategies of bio-oriented agrarian economy development on their national levels.

In accordance with the results of the made investigation before 2005 bio-oriented agrarian economy concept in documents of the European Commission was used for branches, which introduced and used biotechnologies very actively. Nevertheless, later the EC defined this concept as the production of renewable biological resources and their processing into food and feed, other biological products and bioenergy (Innovating for Sustainable Growth: A Bioeconomy for Europe, 2012).

Talavyria M, Lymar V., Baidala V. (2015) argue that biooriented agrarian economy creates the basis for renewable biological resources use and conversion of them into high value added goods, such as food and biofuels. Its sectors have powerful innovation potential thanks using technologies and tacit and explicit knowledge.

Maciejczak M. (2015) argues that from the view of systematic approach bio-oriented agrarian economy is a phenomenon, which has a positive impact on the environment, society, and the economy as a whole by application of innovative technologies in traditional branches, for example, in food production.

In addition, this scientist (Maciejczak, 2015) considers that for retention of utilization, use, and investment the bio-based agrarian economy under the influence of dynamics and stable changes have to create added value on the base of raw materials, which in the future form basis for ecological products. Classical and neoclassical economic theories define three main production factors: labour, land, and capital. Some scientists add to this list entrepreneurship and knowledge. At the time when these factors are actively discussed in the scientific literature, in the new concept like the bio-oriented economy they are not actual ones. Therefore, it is necessary to focus on basic economic assumptions like production functions with the aim to fill the lack in the modern bio-oriented economy understanding to identify the main factors that cause its development.
The bio-oriented agrarian economy has already made huge contributions to stable development and the contribution will grow in the future: higher quality, renewable, natural raw materials will be produced sustainably; food security and a healthy environment will continue to be assured. Conversion to a wider range of final products, whether food, feed, fuel or another healthcare or industrial products, is also sustainable, being efficient, producing little or no waste, and using biological processing. Developing all sectors of the biooriented agrarian economy will promote global food and feed security, improve nutrition and public health, make industrial processing cleaner and more efficient, and make a significant contribution to the effort to minimize climate change. The integrated bio-oriented agrarian economy is not simply only about science but is rather an integration of science with business and community.

On one side, the bio-oriented agrarian economy is a new phenomenon because it studies the economic use and application of renewable biological resources, on the other side, it is an old, maybe in some cases ancient concept because its roots go down deep in the history of food production. It is very simple to prove it because our ancestors used technologies of conservation and utilization of agricultural residues. As a separate field, the bio-oriented agrarian economy is being studied relatively not long ago, approximately from the last two decades of 20th century. Some scientists consider that it is a cross-scientific phenomenon because it connects knowledge of biology, chemistry, gene engineering, economy, and others (Birch, Tyfield, 2012) (Figure 1).

Lymar V., Tsaruk N. (2015) consider that the biooriented agrarian economy encompasses the sustainable production of renewable biological resources and their conversion and that of waste streams into food, bio-based products such as bioplastics, biofuels, and bioenergy. It includes agriculture, forestry, fisheries, food and paper production, as well as parts of chemical, biotechnological, and energy industries. Its sectors have a strong innovation potential due to their use of a wide range of sciences (life sciences, agronomy, ecology, food science, and social sciences), enabling industrial technologies (biotechnology, nanotechnology, information and communication technologies (ICT), and engineering), as well as local and tacit knowledge.

In previous papers, we analysed the knowledge-based bio-economy (KBBE), what has a pretty interest in this investigation too. We defined that the knowledge-based bio-economy is the transformation of life sciences into new, stable, ecological, and competitive products. From the point of view of effectiveness, the knowledge-based bio-economy is the stable management, production, and use of renewable biological resources on the basis of life sciences and biotechnologies.

The knowledge-based bio-economy is based on the next biotechnologies: 


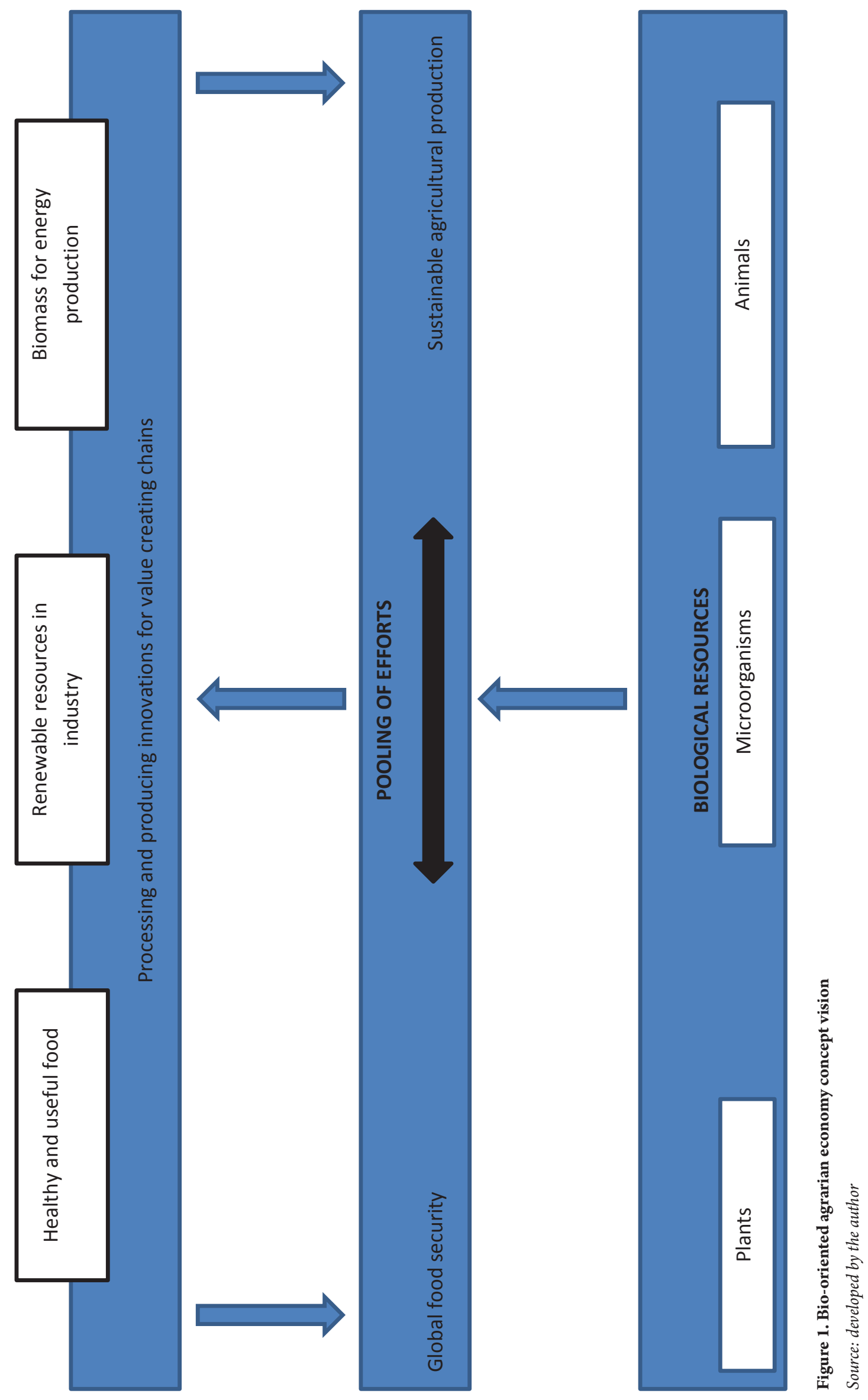


red biotechnologies - production of medical equipment (development of new types of diagnostics and therapy) on the basis of the use of results of genomics and proteomics;

green biotechnologies - implementation agricultura biotechnologies, including renewable energy, produced from remains agricultural products;

white biotechnologies - implementation of biological processes into biochemistry, biopharmaceuticals production, food ingredients production with the aim to make the industry more ecological and less harmful for the environment;

blue biotechnologies - use of aquaculture products for ecological goods.

Knowledge-basedbio-economyis theinterdisciplinary phenomenon and it includes elements of many sciences, namely chemistry, biology, mathematics, physics, computer sciences, and economics.

According to the EC, the bio-oriented agrarian economy consists of the next branches (Table 1).

Table 1

Bio-oriented agrarian economy sectors according to the European Commission classification

\begin{tabular}{|l|c|c|}
\hline \multicolumn{1}{|c|}{ Sector } & $\begin{array}{c}\text { Annual turnover, } \\
\text { billion euro }\end{array}$ & $\begin{array}{c}\text { Employment, } \\
\text { thousands }\end{array}$ \\
\hline Food & 965 & 4400 \\
\hline Agriculture & 381 & 12000 \\
\hline Paper/Pulp & 375 & 1800 \\
\hline Forestry/Wood Industry & 269 & 3000 \\
\hline Fisheries and Aquaculture & 32 & 500 \\
\hline Biochemicals and Plastics & 50 & 150 \\
\hline Enzymes & 0,8 & 5 \\
\hline Biofuels & 6 & 150 \\
\hline Total & 2078 & 22005 \\
\hline
\end{tabular}

According to this table, agriculture occupies the second position with the annual turnover of 381 billion euro in the EU. Therefore, it allows us to presume that for Ukrainian bio-oriented agrarian economy, the gross output of agricultural products is a very significant factor for development.

Given data show the fluctuation of the gross output of agricultural products in Ukraine. The lowest level of the indicator was in 2003, approximately 150 billion hryvnias, the highest one - in 2016 (about 254 billion hryvnias). In 2017, we see a dramatic fall to 150 billion.

Surely, the effectiveness of agriculture is caused by many factors and characterized by instability and dependence on natural factors. Although, government support and investment are defined as very important factors for agriculture and bio-oriented agrarian economy in general.

Bio-oriented agrarian economy ought to be supported by private and public investment what will improve coherence between national, European, and global research and innovation.

Thereby we decided to make a prognosis of the bio-oriented agrarian economy investment in the EU countries and compare indicators with Ukrainian one.

Given analysis is prepared due to the BP Stat program. There were used the next methods: Brown's, Holt's, BoxJenkins, and Olympus. According to our results, the Olympus method is the best one because determination coefficient is 1,000 and approximation error is 0,001. We are not going to show all the steps of calculation because it is not the subject of our investigation.

As we can see, the bio-oriented agrarian economy investment shows the positive dynamics from 2011 to 2025. In 2008, it is seen a dramatic fall from 1656 to

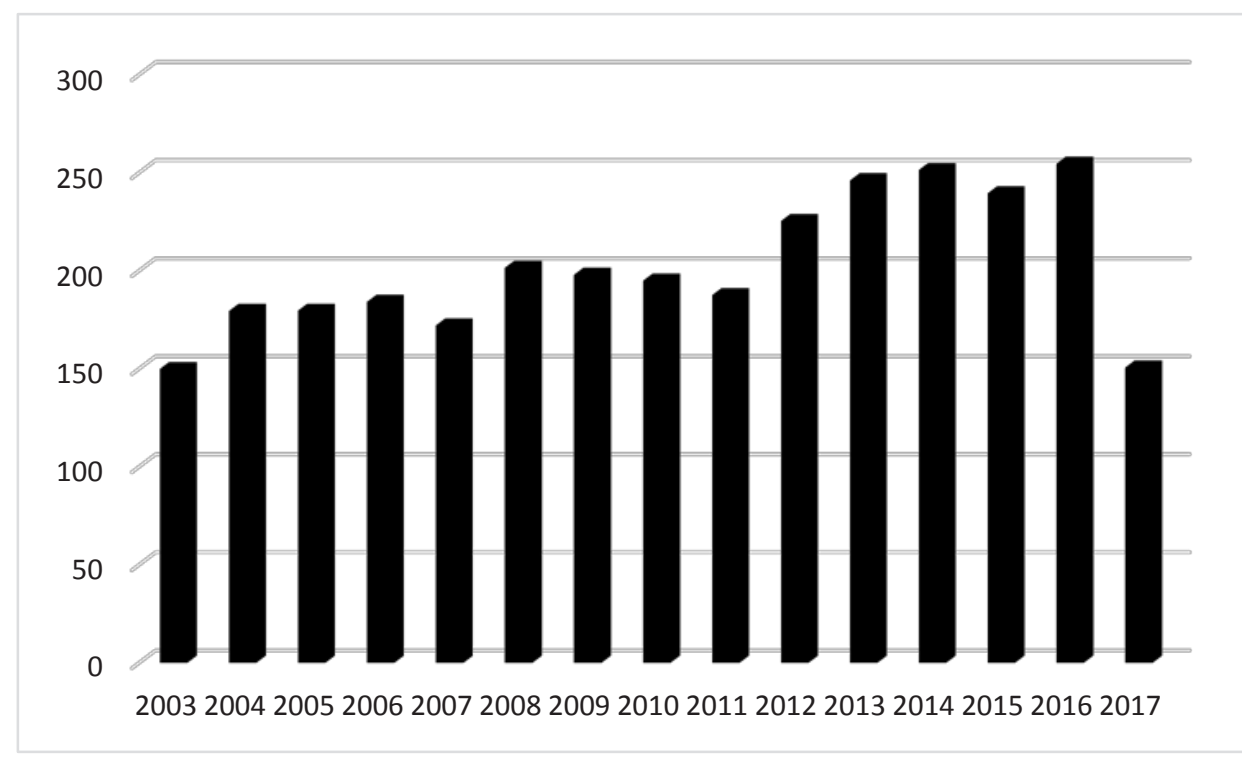

Figure 2. The dynamics of the gross output of agricultural products in Ukraine, 2003-2017, billion hryvnias Source: own calculation based on data from ukrstat.gov.ua 


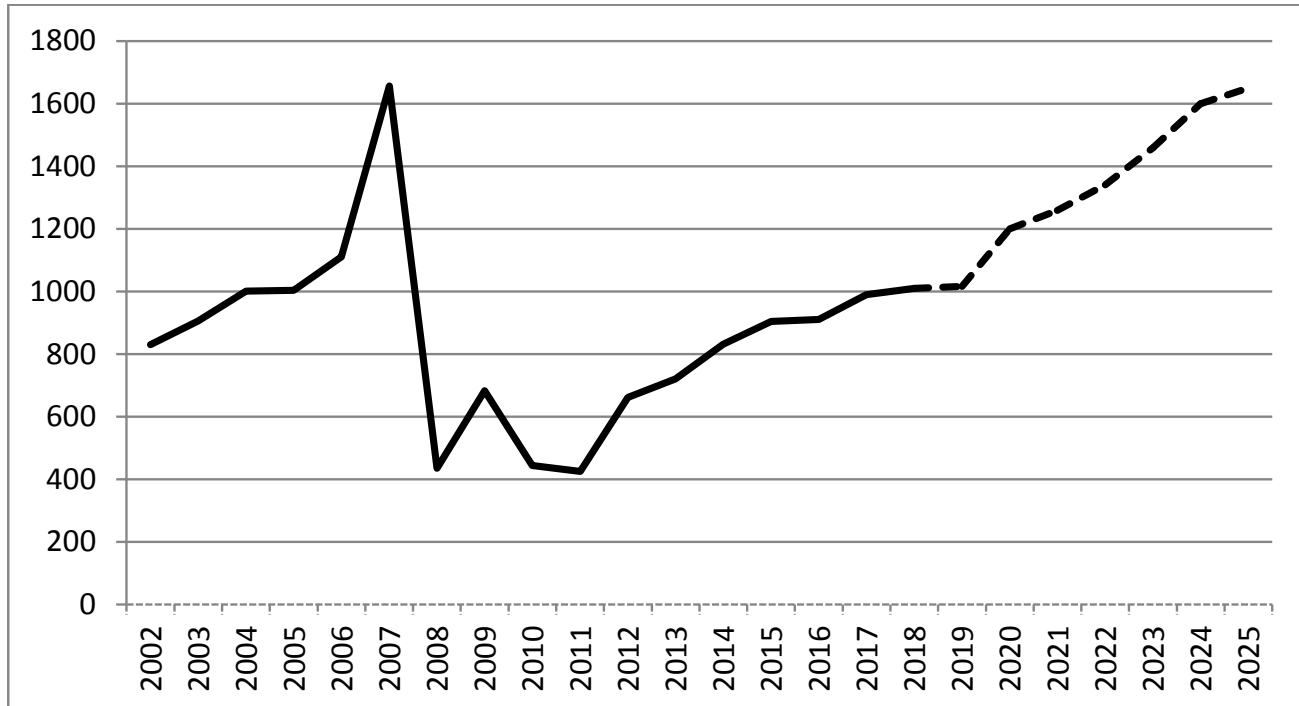

Figure 3. Prognosis model of bio-oriented agrarian economy investment in the EU countries to 2025, billion euro

Source: calculated by the author

435 billion euro. This situation can be caused by the global financial crisis because in this period, all spheres suffered from a lack of finance. From 2011 we can see an increase in investment and hopefully in 2025 it is going to reach 1650 million euro.

There were proposed some recommendations to improve the bio-oriented agrarian economy investment in the EU:

to increase the EU public investments in R\&D related to the bio-oriented agrarian economy, with special efforts on food security, sustainable and green growth, smart use of limited resources;

to promote sufficient national public spending on biooriented agrarian economy research and development; to strengthen synergies between the EU and national programs that support $\mathrm{R} \& \mathrm{D}$ relevant to the biooriented agrarian economy, through specific privatepublic partnering initiatives;

to boost the bio-sciences knowledge base, related emerging technologies and biological research infrastructures, through relevant activities followed by Horizon 2020 "Excellent Science Base";

to cooperate in the area of the bio-oriented agrarian economy, including entrepreneurship promotion activities; to establish close interactions between the relevant parts in Horizon 2020 and other EU programs in areas such as education, science, technology, and knowledge transfer; outline the main research and innovation concepts and priorities for bio-oriented agrarian economy sectors under Horizon 2020.

As we can see, the bio-oriented agrarian economy investment is strongly supported on the EU level. National governments cooperate in spheres of knowledge and technologies transfer, holding common
R\&D, creating start-ups, spin-offs etc. Investment support has the strict vertical from the EU level to university's one. The bio-oriented agrarian economy is one of the most promising in the coming future and its start-ups can be very profitable.

\section{Conclusion}

During our investigation, we got such conclusions. Today in the 21 st century, society faced many problems that have global character; among them are climate changes, food and feed security, air pollution and exhaustion of natural resources. The EU countries reacted very quickly and developed research and innovation program "Horizon 2020" to meet these challenges. In accordance with this program, some European countries developed their own strategies for the development of the bio-oriented agrarian economy.

As we defined, the bio-oriented agrarian economy is not a new phenomenon but rapid development it got after 2005 when it began to be used in the EC documents for sectors, which introduced and used biotechnologies very actively.

There were defined bio-oriented agrarian economy sectors according to the European Commission classification: food, agriculture, paper/pulp, forestry/ wood industry, fisheries and aquaculture bio-chemicals and plastics, enzymes and biofuels.

It was developed the prognosis model of bio-oriented agrarian economy investment in the EU countries to 2025, which shows the positive dynamics from 2011 to 2025.

In our opinion, the successful bio-oriented agrarian economy needs an integrated policy direction with the next key areas: 
investing the relevant research fields, both within each of the sectors and by encouraging inter-disciplinary investigations;

encouraging innovation to be sure that more of the knowledge developments can reach the commercialization stage;

making entrepreneurship within the bio-oriented agrarian economy a promising career option; providing a skilled workforce by making the different sectors of the bio-oriented agrarian economy attractive career options through secondary and tertiary education; developing an innovation-friendly regulatory framework, which balances both risks and advantages; providing high-quality communication with the public embedded in R\&D and innovation projects to ensure societal appreciation of research and innovation.

\section{References:}

Baidala, V. (2016). Bioekonomika v Ukraini: formuvannia, perspektyvy ta makroekonomichni vplyvy [Bioeconomy in Ukraine: formation, prospects and macroeconomics impacts]. Sumy. (in Ukrainian)

Volivach, V., Kozlovska, M., Kravchenko, O. (2016). Formuvannia systemy bioekonomiky v Ukraini [Bioeconomy system forming in Ukraine]. Retrieved from: http://www.researchclub.com.ua/jornal/15 (in Ukrainian)

Matyushenko, I. (2015). Bioekonomika; medychni biotehnologii v sviti I Ukraini [Bioeconomy: medical biotechnologies in the world and in Ukraine]. Retrieved from: http://invest.kh.ua/ru/investor-navigator/ investment-projects/69-library/articles/257-bioekonomika-medichni-biotekhnologiji-v-sviti-i-ukrajini

Selinnyi, M. (2014). Napryamy rozvytku bioekonomiky v Ukraini [Directions of development of bioeconomy in Ukraine]. Retrieved from: http://journals.uran.ua/nvgeci/article/view/24902

Pogrishchyuk, B., Martusenko, I. (2016). Bioekonomichni faktory rozvytku APK [Bioeconomy factors of agriculture development]. Retrieved from: http://ird.gov.ua/pe/re201603/re201603_098_PohrishchukBV,MartusenkoIV.pdf Butenko, V. (2016). Bioekonomika yak mehanizm dosyagnennia tsilei stalogo rozvytku [Bioeconomy like a mechanism of reaching the goals]. Retrieved from: https:/visnyk.mnau.edu.ua/n88v1r2016butenko/

Proshchalkina, A. (2016). Peredumovy stanovlennia ta rozvytku bioekonomiky [Preconditions of becoming and development of bioeconomy]. Retrieved from: http://www.economy.nayka.com.ua/?op=1\&z=5314

Gerasimchuk, N. (2013). Kontseptsiia resursozberezhennia v systemi bioekonomiky [Resources saving concept in the bioeconomy system]. Retrieved from: https://er.knutd.edu.ua/bitstream/123456789/2739/1/20161028_502.pdf

Talavyria, M., Lymar, V., Baidala, V. (2015). Improvement of the bioeconomy development analysis instruments: European Union projects and Germany experience. Ekonomika APK, 11, 89-96.

Kozlovskyi, S., Grynyuk, R., Baltremus, O., Ivashchenko, A. (2017). The methods of state regulation of sustainable development of agrarian sector in Ukraine. Problems and Perspectives in Management (open-access), 15(2-2), $332-343$.

Kozlovskyi, S., Khadzhynov, I., Vlasenko, I., Marynchak, L. (2017). Managing the sustainability of economic system as the basis of investment development in Ukraine. Investment Management and Financial Innovations (open-access), 14(4), 50-59.

Maciejczak, M. (2015). How to analyze bioeconomy? Annals of the Polish Association of Agricultural and Agribusiness Economists. Vol. XVII, 6, 165-171.

Carrez, D. (2008). The bio-based industries initiatives (BBI) and the bio-economy observatory. Retrieved from: https://ec.europa.eu/jrc/sites/default/files/events/20131126-biso-roundtable/20131126-biso-roundtable-carrez.pdf Carlson, R. (2008). Laying the Foundations for a Bioeconomy. USA: Syst Synth Biol, 1(3), 109-117.

Birch, K., Tyfield, D. (2012). Theorizing the bioeconomy. Biovalue, biocapital, bioeconomics or ... What? Retrieved from: http://sth.sagepub.com/content/38/3/299

Goven, J., Pavone, V. (2014). The bioeconomy as political project. A Polanyan analysis. Retrieved from: http://sth.sagepub.com/content/early/2014/10/01/0162243914552133

The Knowledge Based Bio-Economy (KBBE) in Europe: Achievements and Challenges (2010). Retrieved from: http://www.bio-economy.net/reports/files/KBBE_2020_BE_presidency.pdf

Delivering Sustainable Growth by addressing the Grand Societal Challenges (2014). Retrieved from: http://www.epsoweb.org/file/560

The Bioeconomy to 2030. Designing a policy agenda. Main Findings and Policy Conclusions (2009). Retrieved from: http://www.oecd.org/futures/long-termtechnologicalsocietalchallenges/42837897.pdf

Importance of Private and Financial Investors for the Bioeconomy. Current Situation in Europe and Recommendations (2014). Retrieved from http://bioeconomy.miur.it/wp-content/uploads/2014/11/Festel.pdf Innovating for Sustainable Growth: A Bioeconomy for Europe (2012). Retrieved from: http://ec.europa.eu/ research/bioeconomy/pdf/201202_innovating_sustainable_growth_en.pdf

Lymar, V. (2017). Investment support of bio-oriented economy development. Svishtov.

Lymar, V., Tsaruk, N. (2015). Bio-economy: modern global challenges and development supporting policy. Scientific Letters of Academie of Michal Baludansky, 3, 160-163.

Official website of the State Statistics Service of Ukraine. Retrieved from: http://www.ukrstat.gov.ua/

Official website of the Institute of agrarian economy of Ukraine. Retrieved from: http://www.iae.org.ua/ 